\title{
The Effect of Strategic Leadership and Self-Efficacy on Organizational Commitment and Its Implication on Performance Defense Researchers
}

\author{
Muhammad Nakir* \\ Universitas Pertahanan Jakarta \\ Jakarta, Indonesia \\ *nakirnakir@gmail.com
}

\author{
Panjta Djati, Willy Arafah \\ Universitas Trisakti \\ Jakarta, Indonesia
}

\begin{abstract}
This study is aims to analyze the effect of strategic leadership and self-efficacy on organizational commitment and its implications for performance. The research design used in this study is testing the hypothesis. This research is a non-quantitative experiment, using a questionnaire given to 125 respondents. This research was conducted at four defense research and development institutions of the Ministry of Defense, Army, Navy and Air Force, namely Balitbang, in July 2019. Data was analyzed using SPSS and LISREL software. The results obtained: Strategic leadership and self-efficacy has a positive and significant effect on organizational commitment. Strategic leadership and self-efficacy has a positive and significant effect on performance. Organizational commitment has a positive and significant effect on performance. The mediating effect of organizational commitment can increase the effect of strategic leadership on performance, and the mediating effect of organizational commitment can increase the effect of self-efficacy on performance. This study has limitations, including quantitative research with survey methods and data collection processes took place in a short time with a limited number of respondents.
\end{abstract}

Keywords—strategic leadership, self-efficacy, organizational commitment, performance

\section{INTRODUCTION}

In the scope of strategic management, aspects of human resources (HR) become one of the important assets and determine the capability and quality of an organization / institution. Related to this the government, in accordance with President Joko Widodo's direction, has shifted the focus of infrastructure development to human resource development. Observing this, evaluation of the performance of human resources in organizations / institutions is very important for organizational leaders in order to carry out evaluations and plan for human resources in the future. The results of the evaluation of human resource performance can be used as a basis for determining strategic management actions in order to achieve predetermined organizational / institutional goals. This also applies in the organizational environment of the Ministry of Defense of the Republic of Indonesia and the Indonesian Armed Forces (TNI) who continue to optimize performance in order to improve the quality of human resources. The purpose of research and development activities in the field of Defense ( $R$ \& D), as stipulated in the Regulation of the Minister of Defense No. 39 of 2011 concerning Research and Development in the Field of Defense in the Ministry of Defense and the TNI, among others is the achievement of the results of $\mathrm{R} \& \mathrm{D}$ activities in accordance with the specified needs and requirements, and the realization material and nonmaterial readiness of the Ministry of Defense and TNI supported by appropriate technology by the capability of the defense industry. Article 11 Permenhan Number 39 of 2011 also explains that the Ministry of Defense has the authority and responsibility to formulate a So far, the Ministry of Research and Development of the Ministry of Defense organizes research and development programs, both Material and NonMaterial. R \& D Material is conducted by the Center for Defense Equipment Tools and the Center for Defense Science and Technology to support the development of defense equipment. Meanwhile, Non-Material Research and Development is conducted by the Defense Strategy Research Center (Strahan) and the Defense Resources Development Research Center. General description of the total number of $\mathrm{R} \& \mathrm{D}$ programs, Material $\mathrm{R} \& \mathrm{D}$ programs aimed at the development of defense equipment and defense technology, from 2013 to 2018 nd prepare plans, programs and activities for R\&D in accordance with KKIP's grand strategy. In accordance with the explanations and findings of previous studies, individual performance, including the performance of defense researchers, can be influenced by a number of factors, both internal and internal, and external or external to the individual / in the environment organization. Important factors in question include strategic leadership, self-efficacy, and organizational commitment. However, some previous studies have not integrated the variables of strategic leadership, self-efficacy and organizational commitment and performance in an 
integrated study, so that the gap becomes novelty in the research in this dissertation.

\section{LITERATURE REVIEW}

In the theoretical framework discussed relevant concepts related to the variables examined in this study. The concepts discussed include: Performance (Strategic), Strategic Leadership (Strategic Leadership), Self-Efficacy, and Organizational commitment, strategic management, the role of human resources is an important factor that needs to be developed with various activities with the aim of achieving organizational goals. Related to this, the performance of human resources will determine the achievement of organizational goals as expected. According to Robbins in Priansyah [1] the notion of performance leads to an effort to achieve better work performance. A person's success in doing a job is very much determined by performance. Performance is the result of an assessment of a leader in using his resources to carry out a task or work in order to achieve a goal. According to Pounder in Munawaroh [2], individual performance is basically influenced by several factors: (a) expectations regarding rewards, (b) encouragement, (c) abilities, needs and nature, (d) perceptions of tasks, (e) internal rewards and external, (f) perception of the level of reward and job satisfaction. The emphasis of performance is to get results oriented towards effectiveness and efficiency to achieve a goal. Thus, it can be stated that performance is the result, both quantity and quality, achieved by a person in carrying out his tasks in accordance with predetermined standards or criteria so as to achieve the expected goals effectively and efficiently. Performance appraisals provide many important uses for the organization as a forum for activities for a group of people who work together in achieving goals. Basically, performance appraisal is one of the key factors to develop an organization effectively and efficiently, because of a policy or work performance appraisal program, meaning that the organization has made good use of the human resources within the organization. Based on the results of the study, the value of IWPQ task and contextual performance showed a positive correlation with work engagement. The counterproductive value of work behavior shows a weak to moderate negative correlation with work engagement. Interestingly, this study shows that work engagement correlates more strongly with contextual behavior than with task behavior and counterproductive behavior. Finally, IWPQ is able to differentiate between relevant groups. As predicted, the results of this study show that people with high job satisfaction show higher task and contextual values and lower counterproductive work behavior values, compared to people with lower job satisfaction levels. In addition, people with high health exhibit higher IWPQ task and contextual scores and low counterproductive work behavior IWPQ scores. Strategic leadership, according to Rowe [3], is the ability to influence people to make decisions in daily activities simultaneously that will improve the survival of the organization in the long run. Rowe stated that strategic leadership is a combination of managerial leadership and visionary leadership. Managerial leadership is leadership directed to achieve the goals set as a need, not as a dream or an ideal hope [4]. Whereas visionary leadership is leadership that is always future-oriented and dare to take risks. Visionary leaders have advantages in terms of creativity and innovation in implementing the vision that has been set. In addition, leadership is seen by Elenkov and Manev [5] as a process of forming the organization's future vision which is then communicated to members of the organization with the aim to motivate and encourage all members to be involved and support in the development and implementation of strategies. According to Jooste and Heleta [6], strategic leadership is the ability of leaders to anticipate, imagine, maintain flexibility, and delegate authority to others to create the strategic changes needed by organizations.

In carrying out an activity, individual success is not only determined by the knowledge and expertise they have. A person's performance may not be optimal or even fail even though he has adequate knowledge and expertise. Feist [7] then uses the term self-efficacy to explain the factors that play a role behind this frequent gap between action and knowledge. Selfefficacy is one's belief in one's ability to organize and take actions needed to achieve a certain level of performance. According to Bandura, self-efficacy is not directly related to skills possessed by individuals, but to self-assessment of what can be done from what can be done, without being related to the skills possessed. The basic concept of self-efficacy theory is the problem of the belief that each individual has the ability to control his thoughts, feelings and behavior. Self-efficacy is a matter of subjective perception. Self-efficacy does not always describe the true ability, but is related to the beliefs that individuals have. Function according to Bandura consists of: First, choice of behavior; second, the durability and magnitude of individual effort; third, individual's thinking patterns and emotional reactions, and; fourth, individual behavior.

Organizational commitment is an individual employee variable that has an important role in achieving organizational goals [8]. High commitment will encourage employees to make positive efforts that can contribute to the optimization of the implementation of tasks. Coleman et al., [9] organizational commitment reflects a sense of identification (trust in organizational values), involvement (willingness to do their best for the sake of the organization) and loyalty (the desire to remain a member of the organization concerned) expressed by an employee of the organization. Meanwhile for now day, Belton [10] states organizational commitment is a relative strength of the individual in identifying his involvement in the organization, which is characterized by three things: employee acceptance of organizational values and goals, employee readiness and willingness to strive earnestly on behalf of the organization, and the desire of employees to maintain their membership in the organization (become part of the organization). In the context of organizational life, commitment is interpreted differently by experts. Shaw and Shaws [11] for example interpret commitment as a result of investment or contribution to the organization, or a psychological approach that describes commitment as a positive thing, high 
involvement, high intensity orientation towards the organization [12].

\section{METHODS}

Sharma [13] research results show a positive relationship between self-efficacy and organizational commitment among employees, where self-efficacy is the most powerful predictor of organizational commitment. According to Nawaz and Koç [14], self-efficacy and organizational commitment have been identified by researchers as interdependent where the role of self-efficacy is in changing motivation, and there is an effect of self-efficacy in modifying the level of commitment to work. Gadkari et al., [15] found that employee commitment was significantly related to self-efficacy. Thus the hypothesis can be put forward that:

$\mathrm{H1}$ : there is an influence of strategic leadership on organizational commitment of defense researchers.

$\mathrm{H} 2$ : There is an influence of self-efficacy on organizational commitment of defense researchers.

Othman et al., [16] found that job embeddedness, selfefficacy, and organizational commitment significantly influence employee performance and organizational performance. In addition, employee performance was found to be significant and mediate the effects of job embeddedness, self-efficacy, and organizational commitment on organizational performance. Thus the hypothesis can be put forward that:

H3: There is an influence of strategic leadership on the performance of defense researchers.

H4: There is an effect of self-efficacy on the performance of defense researchers.

H5: There is an influence of organizational commitment on the performance of defense researchers.

Based on the results of various studies above that show a mediation relationship and similar effects between research variables, the hypothesis can be put forward that:

H6: There is an influence of strategic leadership through organizational commitment on the performance of defense researchers.

H7: There is an effect of self-efficacy through organizational commitment on the performance of defense researchers.

H8: There is an influence of strategic leadership and selfefficacy on organizational commitment.

H9: There is an influence of strategic leadership, selfefficacy and organizational commitment on performance

\section{DISCUSSION}

In this study the responses or respondents to the research variables are through descriptive analysis of each indicator.
The variables in this study consisted of strategic leadership, self-efficacy, organizational commitment and performance.

General respondents perceive strategic leadership very well. The respondent's perception in perceiving the highest strategic leadership is on SL3's statement that "human resource development is important to be able to produce superior R\&D products"; with an average score of 4.39. While the lowest average score perceived by respondents was in SL6's statement, "R \& D should emphasize ethical practices that have been rated as good"; with an average score of 3.93 .

Self-efficacy variable has an average score of 4.16 which is in the very good / very agree category. This shows that in general respondents perceive self-efficacy very well. The respondent's perception in perceiving the highest self-efficacy was in the SE8 statement: "I am willing to maintain good relations with my direct supervisor"; with an average of 4.23. While the lowest average score perceived by respondents was in the SE2 statement, namely "I am able to achieve the target of the work given"; with an average score of 4.08 .

Organizational commitment variable has an average score of 3.88 which is in the category of good / agree. This shows that in general respondents perceive organizational commitment well. The respondent's perception in perceiving organizational commitment was highest in the OC5 statement that is "I feel to be a 'part of my family' in my work unit"; with an average score of 4.18 . While the lowest average score perceived by respondents is in the OC16 statement, "One of the main reasons for continuing to work in my current work unit is the possibility of risk of not obtaining benefits comparable to those obtained now when working elsewhere" with a score an average of 3.68 .

Performance variable data has an average score of 4.12 which is in the excellent / very agree category. This shows that in general respondents perceive performance very well. As for the perception of respondents in perceiving the highest performance is in the statement P18, namely "I talked to outsiders about positive things about my office"; with an average score of 4.34 , while the lowest average score perceived by respondents was in the P5 statement, namely "I did a good job in time and with minimal effort"; with an average score of 3.90 .

\section{CONCLUSION}

The following research findings can be summarized. The influence of strategic leadership and self-efficacy on organizational commitment is positive and significant. The influence of strategic leadership and self-efficacy on performance is positive and significant. The effect of organizational commitment on performance is positive and significant. Organizational commitment has a positive and significant effect on performance. The influence of strategic leadership, self-efficacy and organizational commitment together on performance is positive and significant with organizational commitment [17]. 


\section{REFERENCES}

[1] R. Priansyah, "Single Axis Quadcopter using Proportional Integral Derivative (PID) based Labview," Telekontran J Ilm Telekomun Kendali dan Elektron Terap., 2016.

[2] Munawaroh, "The Influence of Teaching Methods and Learning Environment to the Student's Learning Achievement of Craft and Entrepreneurship Subjects at Vocational High School,’ Int J Environ Sci Educ., 2017.

[3] F. Rowe, "What literature review is not: Diversity, boundaries and recommendations," European Journal of Information Systems, 2014.

[4] E.O. Roldan and J. Dickerman, "Leadership. In: Succeeding in Academic Medicine: A Roadmap for Diverse Medical Students and Residents" 2020.

[5] D.S. Elenkov and I.M. Manev, "Top management leadership and influence on innovation: The role of sociocultural context," J Manage., 2005.

[6] N. Jooste and S. Heleta, "Global Citizenship Versus Globally Competent Graduates: A Critical View From the South,” J Stud Int Educ., 2017.

[7] J. Feist and G.J. Feist, Teori Kepribadian, Jilid 2, 2017.

[8] F. Stinglhamber, G. Caesens, L. Clark, and R. Eisenberger, "Perceived organizational support," Handbook of Employee Commitment, 2016.

[9] L.W. Coleman, R.E. Hickson, N.M. Schreurs, N.P. Martin, P.R. Kenyon, and N. Lopez-Villalobos, "Carcass characteristics and meat quality of Hereford sired steers born to beef-cross-dairy and Angus breeding cows," Meat Sci., 2016.

[10] P. Belton, "Competitive Strategy: Techniques for Analyzing Industries and Competitors," Competitive Strategy: Techniques for Analyzing Industries and Competitors, 2017.

[11] S. Shaw and S. Shaw, "Airline Marketing and Management," Airline Marketing and Management, 2016.

[12] M. Grant and M. Weir, "The world health organization," in: The International Handbook of Addiction Behaviour, 2016.

[13] S. Sharma and M. Warkentin, "Do I really belong?: Impact of employment status on information security policy compliance," Computers \& Security, 2019.

[14] W. Nawaz and M. Koç, "Development of a systematic framework for sustainability management of organizations," Journal of Cleaner Production, 2018.

[15] S.S. Gadkari, Q.B. Maskati and B.K. Nayak, "Prevalence of diabetic retinopathy in India: The All India Ophthalmological Society Diabetic Retinopathy Eye Screening Study 2014," Indian J Ophthalmol, 2016.

[16] I. Othman, R. Majid, H. Mohamad, N. Shafiq and M. Napiah, "Variety of Accident Causes in Construction Industry," In: MATEC Web of Conferences, 2018.

[17] H.J. Klein and H. Park, "Organizational Commitment," in International Encyclopedia of the Social \& Behavioral Sciences: Second Edition, 2015 . 